\title{
Cultivating Intercultural Competence and Critical Thinking Skills in Chinese Culture Oriented Foreign Teaching
}

\author{
Bo Song \\ Applied Foreign Languages College \\ Tianjin Sino-German University of Applied Sciences \\ Tianjin, China
}

\begin{abstract}
The cultivation of technical international talents is the primary task and the fundamental requirement. The intercultural competence and critical thinking skills which attach great importance to bilingual and bicultural competence are core qualities for technical international talents and the ultimate aim for foreign teaching in applied sciences university as well. However, the foreign culture weighs more than Chinese culture in real teaching. It is more advisable that more attention should be paid to excellent Chinese culture. As it contributes to improving the cultural comparative awareness and cultivate the intercultural competence and critical thinking skills.
\end{abstract}

Keywords-Chinese culture; intercultural competence; critical thinking skills; foreign teaching

\section{INTRODUCTION}

The trend of internationalization in school-running is obvious and influential. The foreign language skill is the indispensable requirement for higher education under the direction of internationalization. In foreign language learning, students are prone to be affected by their native languages. So they can't adapt themselves to foreign culture and probably experience the culture shock as well. Intercultural competence and critical thinking skill are the two core qualities in foreign language learning. To play the positive role in foreign language learning, it is necessary to attach great importance to the cultivation of intercultural competence and critical thinking skills. The Guidance to College English Teaching shows that the foreign teaching isn't only a matter of language learning, but also the imparting humanistic education where Chinese culture is often overlooked while the western culture is paid much attention to. Therefore we should strike a balance between the two cultures. We should bear in mind that Chinese culture is important and priceless in foreign language learning. Only by conserving the Chinese culture can we better command a foreign language.

\section{STRENGTHENING THE EXCELLENT ChINESE CULtURE TEACHING IN FOREIGN STUDY}

With the development of society and increasing international exchanges nowadays, the sources of knowledge are extensive and diverse. Students are likely to be affected by the multi-cultures because of the cultural and ideological differences. President $\mathrm{Xi}$ stressed in the National Ideology and Politics Work Meeting of Higher Education that all educators should pay more attention to the ideological education of college students not only imparting the knowledge. It is also essential for college foreign language teachers to give a positive response to the call. We should penetrate the Socialist Core Values which are closely connected with excellent traditional Chinese culture into foreign teaching. It means that we should attach great importance to the education of excellent Chinese culture in foreign teaching.

In addition, the improving comprehensive strength and the rising international status of China show that there are more needs to publicize Chinese voices and thoughts in international stage. To meet current condition, the foreign language teaching shouldn't emphasize the introduction to foreign cultures and advanced philosophies. We should make the voice of China heard and spread to the rest of the world. The Chinese new thoughts and advanced technologies can be introduced to other countries. Students should learn more foreign expressions about Chinese culture, and have a stronger sense of cultural intimacy and identification. It is meaningful for students in foreign language learning if the great importance is attached to Chinese cultures. It is helpful for students to publicize China and Chinese culture in the foreign context. The penetration of the excellent Chinese culture in foreign learning is a good way to improve intercultural competence and adaptation by the cultura comparison and differences distinguishing.

\section{THE INNER CONNECTIONS BETWEEN INTERCULTURAL COMPETENCE AND CRITICAL THINKING SKILLS}

Intercultural competence refers to an ability that the communicators can effectively and appropriately communicate with others in the context of different cultures, 
social norms and values. It includes communicative competence and cultural creativity. The communicative competence can be divided into linguistic competence and pragmatic competence. From the perspective of knowledge, linguistic competence contains phonetics, vocabulary and grammar. From the perspective of skills, it involves the skills of listening, speaking, reading, writing, translating. In linguistics, pragmatic competence is the ability to use language effectively in a contextually appropriate condition. Pragmatic competence is a fundamental aspect of a more general communicative competence.

Critical thinking skills can be traced back to several hundred years ago. The book of rites says "learn extensively, inquire thoroughly, ponder prudently, discriminate clearly, and practice devotedly” (博学之, 审问之, 慎思之, 明辨 之, 笃行之), which indicates the importance of critical thinking. "The encouragement of a questioning spirit" from Cambridge University and "rejoice in discovery and in critical thought" from Harvard University, both highlight the significance of critical thinking too. The famous American educator Peter Facione says the essence of education is learning to think independently.

Higher Education Law of China stipulates that the fundamental purpose of higher education is to cultivate the senior professional talents with innovation and practicality whose core quality is critical thinking. The critical thinking provides intelligent support for the talents, forges and improves the practicality. According to the latest released Guide to College English Teaching, College English is one important part of humanistic education in higher education, possessing the characteristics of the instrument and humanism. For the humanism, the main task of college English is to conduct the intercultural education. In fact, the intercultural competence and critical thinking skills are the two core cultivating targets for the higher education.

To get better understanding of the connection between intercultural competence and critical thinking skills, it is essential to know the connection between intercultural communication and critical thinking. As a special communication way between the native culture and foreign culture, the intercultural competence is closely related to the critical thinking. On the one hand, the critical thinking is on the basis of communication. The critical thinking skills are improved by interpersonal communication. So the critical thinking plays an important role in daily communication by making inference and forming the persuasive opinion. A person with a dialectical point of view and strong critical thinking skills probably can be a good communicator. On the other hand, communication contributes to critical thinking. The more communication people have, the more effective and considerate reaction people will have. The communicator with strong critical thinking skills can make more prudent assessment after a series of serious reflection, comparison and measurement. Therefore, people can solve the problem in a proper and reasonable way. The critical thinking affects people's actions in different levels whatever in sensation or in cognition. As an important and dispensable part of people's lives, the effect of communication is determined in some extend by the critical thinking skills. In a word, the intercultural competence and critical thinking skills are closely connected with each other. They are mutually promoted and affected.

\section{THE STRATEGIES FOR CULTIVATING INTERCULTURAL COMPETENCE AND CRITICAL THINKING SKILLS IN CHINESE ORIENTED FOREIGN TEACHING}

Integrating the Chinese culture into foreign teaching is an effective way to improve students' intercultural competence and critical thinking skills by comparison and contract. The concrete strategies can be carried out in the following three steps:

\section{A. Improving the teacher's moral and professional qualities}

Foreign teacher is the main body for foreign teaching, and also the important source of knowledge. So the foreign teacher needs to improve his knowledge reservation and enrich his teaching skills. Firstly, the foreign teacher should actively engage himself in improving his bilingual languages skills. The foreign teacher should know more Chinese and western cultures, especially the excellent traditional Chinese culture, which is the essence of our merits. Secondly, the foreign teacher should spare no efforts improving his teaching techniques. Attentions should be paid to the teaching in intercultural communication and critical thinking. All activities should be implemented on the basis of those two principles. Meanwhile the foreign teacher should set up more open questions to encourage students' active participations. The foreign teacher should also conduct students to make comparisons between Chinese and foreign cultures, to increase the language senses and distinguishing awareness. Last but not least, the foreign teacher should possess a firm political status, and publicize the positive concepts and opinions to students. As the great impacts on students by his words and behaviors, the foreign teacher should have an optimistic attitude towards life and value. Facing the great differences between Chinese and western culture, the foreign teacher should not only focus his attention on foreign teaching, but set up a good model for students and educate them in an all round way.

\section{B. Optimizing the teaching contents with excellent Chinese culture}

The teaching contents should be based on excellent Chinese culture which is being passed down for many generations. The Chinese culture is extensive and profound. We should carry it down and integrate it into foreign teaching. The foreign teaching doesn't simply introduce the advanced western culture and technologies to China any more. It is necessary to take the responsibility to publicize our excellent culture in foreign language and make it known by the rest of the world. On the basis of the differences between Chinese and foreign cultures, the teacher should carefully explore their deep cultural connotation, clearly deliberate their differences, and instruct students to think comparatively and independently. Specifically, the teaching contents based on Chinese culture, are supposed to improve students' communicative competence which are related to 
daily use. In the higher grade, the teaching content should involve some common professional knowledge with an aim for the career future.

\section{Updating the teaching modes with experiential learning}

The experiential learning which is also called doing by learning is one of effective way for learning. The practical teaching should create more chances for students to experience different cultures by thinking, comparing and analyzing so that the intercultural competence and critical thinking skills can be internalized in students' qualities. The foreign language teacher puts forward some heuristic questions for discussion to arouse the desire for questioning and analyzing. It is also feasible for teacher to ask students to do the intercultural role-play, read intercultural cases, and watch intercultural movies, etc. It can be also carried out of class, such as international communication, foreign practicum and so on.

Moreover, the foreign language teacher can try to make the online intercultural communication resources in the form of text, audio and video to facilitate students learning independently and flexibly.

\section{CONCLUSION}

With the advancing economic globalization, promoting Chinese dream of great rejuvenation, and deepening cooperation with the rest of the world, the Chinese civilization is intertwined with world civilization. Guided by Chinese dream, exchanges and mutual learning are more frequent than ever before. Therefore, there is a larger need for qualified talents with strong intercultural competence and critical thinking skills. In foreign teaching, it is essential to carry out common humanistic education by comparison between Chinese and foreign cultures to enlighten students, broaden their horizons, and promote thinking independently with an inclusive and open attitude. The cultivation of intercultural competence and critical thinking skills is supposed to be integrated into the cultivation of a qualified talent in all round development. Only by this can we develop comprehensive, innovative and competitive graduates for modern society and contribute to prosperous wealthy great nation.

\section{REFERENCES}

[1] The remarks of Xi Jinping at National Ideology and Politics work conference.

http://www.moe.edu.cn/jyb_xwfb/s6052/moe_838/201612/t20161208 _291306.html, 17/8/2017

[2] The speech of $\mathrm{Xi}$ Jinping at UNESCO. http://news.xinhuanet.com/world/2014-03/28/c_119982831_3.html. $18 / 8 / 2017$

[3] Sun Youzhong, the cultivation of intercultural competence and foreign education [J], Foreign Languages in China 2016(5), pp.17-22

[4] Sun Youzhong, the cultivation of Critical Thinking Skills and foreign education [J], Foreign Languages in China 2015(2), pp. 19-23

[5] Shen Juming,\& Gao Yongchen, Interaction: Critical thinking Skills and Intercultural competence [J], Journal of Suzhou University, 2015(3), pp. 149-154.
[6] Yin Rui, Cultivating the Critical Thinking Skills in Intercultural Communication -A Case of the Comparison in Chinese and Western Cultures [J], Foreign Languages in China 2014(5), pp. 91-98. 